\title{
IAMJ
}

INTERNATIONAL

AYURVEDIC

MEDICAL JOURNAL

Case Report

ISSN: 2320-5091

Impact Factor: 6.719

\section{COMPLETE MANAGEMENT OF ARDITA (BELL'S PALSY) AS PER AYURVEDA CHIKITSA SUTRA - A CASE REPORT}

\author{
$\underline{\text { Ram Lakhan Meena }}{ }^{1}$, Santoshkumar Bhatted ${ }^{2}$, Nilam Meena ${ }^{3}$ \\ ${ }^{1}$ Assistant Professor, Department of Panchakarma, Shri Dhanvantari Ayurvedic College and Research Center, \\ Mathura, Uttar Pradesh, India \\ ${ }^{2}$ Associate Professor and Head of Department \\ Department of Panchakarma, All India Institute of Ayurveda, Sarita Vihar, New Delhi, India \\ ${ }^{3}$ Assistant Professor, Department of Kayachikitsa, Shri Dhanvantari Ayurvedic College and Research Center, \\ Mathura, Uttar Pradesh, India
}

Corresponding Author: drramlakhanm@gmail.com

https://doi.org/10.46607/iamj2209032021

(Published online: March 2021)

Open Access

(C) International Ayurvedic Medical Journal, India 2021

Article Received: 06/02/2021 - Peer Reviewed: 14/02/2021 - Accepted for Publication: 17/02/2021

(D) Check for updates

\begin{abstract}
Bell's palsy, also known as acute idiopathic lower motor neuron facial paralysis, is characterized by sudden onset paralysis or weakness of the muscles to one side of the face controlled by the facial nerve. In contemporary science, administration of steroids is the treatment of choice for complete facial palsy. Certain Panchakarma procedures and internal Ayurvedic medicines have been proved to be beneficial in the management of Ardita vata. The present report deals with a case of 62-year-old male patient diagnosed as Ardita vata was treated with various Panchakarma procedures like Nasya, Shirobasti, Kukkutanda Swedana, Dashmoola Ksheer Dhoom, Gandoosh and oral Ayurveda medicines. Criteria of assessment was based on the scoring of House-Brackmann Facial Nerve Grading scale. After completion of Ayurveda treatment, the patient Shown almost complete recovery without any adverse effects. This case is an evidence to demonstrate the effectiveness of Ayurveda treatment in case of Ardita vata (Bell's palsy).
\end{abstract}

Keywords: Bell's palsy, Nasya, Shirobasti, Gandoosh, Ardita Vata 


\section{INTRODUCTION}

Bell's palsy, also called idiopathic facial paralysis, is defined as an acute-onset, isolated, unilateral, lower motor neurone facial weakness. ${ }^{1}$ It is associated with the presence of herpes simplex virus type 1 DNA in endoneurial fluid and posterior articular muscle. The annual incidence of this idiopathic disorder is between 11 and 40 per 100,000 annually, or about 1 in 60 person in a life time. ${ }^{2}$ The early effect of Bell's palsy is inability to fully close the mouth and eye on the affected side of the face, causing difficulties in eating and speaking, corneal drying and erosion. Later symptoms can include pain around the ear sometimes extending to the back of head or neck, altered taste, synkinesis, facial spasm, facial contractures, dysfunctional lacrimation and noise intolerance. ${ }^{3}$ The subsequent disability of oral fitness, verbal correspondence, and social connection can add to critical significant emotional distress during Bell's palsy. ${ }^{4}$ On the basis of symptomatology, this condition can be correlated with Ardita vata in Ayurveda (Table 1$)^{5}$

Table 1: comparison of Bell's palsy with Ardita Vata

\begin{tabular}{|l|l|}
\hline Bell's palsy & Ardita Vata \\
\hline Deviation of mouth towards left side & Vakreebhavati vaktrardham Vakreekaroti nasa bhru lalata akshi hanustatha \\
\hline Watering of eyes & Netramaavilam \\
\hline Unable to blink the eye of affected side & Stabdham netram, Ekasya aksho nemeelanam \\
\hline sudden onset of deviation of mouth and weakness & Samutkshipteti atitwaritah \\
\hline Slurred speech & Vaak sanga \\
\hline
\end{tabular}

The treatment strategy generally includes administration of glucocorticoids along with antiviral agents and massage of the weakened muscles. The treatment of Bell's palsy aims to speed recovery and reduce longterm complications. It is known that inflammation and oedema of the facial nerve are responsible for the symptoms. Corticosteroids have therefore been used for their anti-inflammatory effect. An inability to close the eye on the affected side increases the risk of corneal complications hence eye patch, eye drops and lubricants are used to prevent drying of the cornea. ${ }^{7}$ In Ayurveda, the treatment principle of Ardita disease mainly includes Navana (Nasya) (nasal administration of fatty substance like herbal medicated oil/ghee), Moordhni Taila (different modalities of retaining herbal medicated oil over the head for 30 to 60 minutes), Tarpana Chikitsa (retaining of herbal medicated oil over the eyes for few minutes), Nadi Swedana (fomentations with the help of tubular structures), Upanaha (poultice) with Anoopa mamsa (meat of animals residing in Marshy land) is the line of treatment mentioned for $\mathrm{Ar}$ dita. ${ }^{\mathbf{8}}$ Here is a case where almost complete recovery was observed by administering these above Ayurveda therapies with some oral medication.

\section{Case Report}

A 62 year old moderately built male patient, belonging to middle class household, visited to Panchakarma OPD of AIIA with the complaints of deviation of mouth towards left side (Vakreekaroti nasa bhru lalata akshi hanustatha), watering of eyes (Netram aavilam), unable to blink eyes (Stabdha netram, Ekasya aksho nemeelanam), difficulty in chewing food on the right jaw (Bhojanamiti na samam mukhena khadati), drooping of food particles with saliva from mouth and pricking pain in right eye since three months. He consulted a physician for the condition where he was diagnosed as a case of Bell's palsy. He had a history of excessive exposure to wind due to bike riding before the manifestation, due to which he developed watering of eyes with mild headache. Next day in morning, he had sudden onset of deviation of mouth to the left side (Samutkshipteti atitwaritah), Inactivity of eyelid movement of right eye, difficulty in speech (Vaak sanga) and escaping water from mouth. There was no history of diabetes mellitus, hypertension, thyroid disorder or any other infectious disorder. According to patient's report treatment was started with steroids for a period of 10 days. As satisfactory results were not observed, patient stopped 
the use of steroids against medical advice before two months of consultation for Ayurvedic treatment.

\section{Physical Examination}

The physical examination at the time of hospital visit of the patient revealed a body temperature of $98.8^{\circ} \mathrm{F}$, pulse rate -76 beats/min, respiratory rate of 19 times/min, blood pressure of $110 / 70 \mathrm{mmHg}$, and normal oxygen saturation. No sign and symptoms of any systemic illness was found on systemic examination. All routine investigations including blood and urine were done which was within the normal limits.

Higher mental functions were intact with motor functions of the affected facial nerve. Deviation of mouth towards left side was observed during clenching of teeth and while puff out cheeks, Mouth deviated on left side and leakage of air through the left angle of mouth observed on an act of filling of air in mouth. Complete closure of the right eye was not possible and unable to raise the right eyebrow with absent wrinkles on the right side of the forehead, indicating the affected motor function of the facial nerve.

\section{Pathogenesis}

Due to the excessive exposure to cold wind, vitiated Vata with Kapha are involved in the pathogenesis of the disease. Prakupita vata (aggravated vata) along with Kapha settles in Sandhi (joints of above clavicle) of Shira (head), Nasa (nose), Hanu (mandible), Lalata (forehead) and Netra (eye). Snayu ( ligaments) and Kandara ( $\sim$ muscles) are affected by the aggravated Doshas and presented symptoms on the left half of the face with all the features of Ardita vata. This condition is similar to Bell's palsy in contemporary science, where the facial nerve palsy presenting with above symptoms is seen.

\section{Assessment Criteria}

Table 2: House-Brackmann Facial Nerve Grading Scale ${ }^{9}$

\begin{tabular}{|l|l|l|l|}
\hline \multicolumn{2}{|l|}{ House-Brackmann Facial Nerve Grading Scale } \\
\hline Grade & Defined by \\
\hline 1 & Normal & Normal facial function in all areas \\
\hline 2 & $\begin{array}{l}\text { Mild dys- } \\
\text { function }\end{array}$ & $\begin{array}{l}\text { Slight weakness noticeable only on close inspection. At rest: normal symmetry of forehead, ability to } \\
\text { close eye with minimal effort and slight asymmetry, ability to move corners of mouth with maximal effort } \\
\text { and slight asymmetry. No synkinesis, contracture, or hemifacial spasm }\end{array}$ \\
\hline 3 & $\begin{array}{l}\text { Moderate } \\
\text { dysfunction }\end{array}$ & $\begin{array}{l}\text { Obvious, but not disfiguring difference between two sides, no functional impairment; noticeable, but not } \\
\text { severe synkinesis, contracture, and/or hemifacial spasm. At rest: normal symmetry and tone. Motion: } \\
\text { slight to no movement of forehead, ability to close eye with maximal effort and obvious asymmetry, } \\
\text { ability to move corners of mouth with maximal effort and obvious asymmetry. Patients who have obvious, } \\
\text { but no disfiguring synkinesis, contracture, and/or hemifacial spasm are grade III regardless of degree of } \\
\text { motor activity. }\end{array}$ \\
\hline 4 & $\begin{array}{l}\text { Moderately } \\
\text { severe dys- } \\
\text { function }\end{array}$ & $\begin{array}{l}\text { Obvious weakness and/or disfiguring asymmetry. At rest: normal symmetry and tone. Motion: no move- } \\
\text { ment of forehead; inability to close eye completely with maximal effort. Patients with synkinesis, mass } \\
\text { action, and/or hemifacial spasm severe enough to interfere with function are grade IV regardless of motor } \\
\text { activity. }\end{array}$ \\
\hline 5 & $\begin{array}{l}\text { severe dys- } \\
\text { function }\end{array}$ & $\begin{array}{l}\text { Only barely perceptible motion. At rest: possible asymmetry with droop of corner of mouth and decreased } \\
\text { or absence of nasal labial fold. Motion: no movement of forehead, incomplete closure of eye and only } \\
\text { slight movement of lid with maximal effort, slight movement of corner of mouth. Synkinesis, contracture, } \\
\text { and hemifacial spasm usually absent. }\end{array}$ \\
\hline 6 & $\begin{array}{l}\text { Total paral- } \\
\text { ysis }\end{array}$ & \begin{tabular}{l} 
Loss of tone; asymmetry; no motion; no synkinesis, contracture, or hemifacial spasm. \\
\hline
\end{tabular} \\
\hline
\end{tabular}


Assessment was done on the basis of House-Brackmann Facial Nerve Grading scale of facial nerve weakness showed that there is grade IV of facial paralysis as shown in table 2.

\section{Panchakarma Procedure Adopted}

Panchakarma procedure like Nasya, Kukkutanda swedana $^{\mathbf{1 0}}$ (fomentation with the help of egg yolk),
Ksheerdhoom ${ }^{11}$ (fomentation with the help of herbal medicated milk), and Shirobasti ${ }^{12}$ (retention of oil on scalp for 30 to 60 minutes) were carried out as per classical method. Treatment was done as mentioned in table 3 .

Table 3: Therapeutic Intervention

\begin{tabular}{|c|c|c|c|}
\hline Procedure & Medication & Dose & Duration \\
\hline $\begin{array}{l}\text { Mukha Abhyanga (face mas- } \\
\text { sage) }\end{array}$ & Ksheer Bala Taila ${ }^{\mathbf{3}}$ & $50 \mathrm{ml}$ & $\begin{array}{l}1^{\text {st }} \text { to } 14^{\text {th }} \text { day }(14 \\
\text { days) }\end{array}$ \\
\hline Kukkutanda swedana & $\begin{array}{l}\text { Kolakulatthadi churna } \mathbf{1 4}^{\mathbf{4}} \\
\text { Methika } \\
\text { Haridra } \\
\text { Lemon } \\
\text { Yolk of egg }\end{array}$ & $\begin{array}{l}500 \mathrm{gm} \\
100 \mathrm{gm} \\
100 \mathrm{gm} \\
1 \text { piece } \\
10\end{array}$ & $\begin{array}{l}1^{\text {st }} \text { to } 7^{\text {th }} \text { day } \\
\text { ( } 7 \text { days) }\end{array}$ \\
\hline Dashmoola ksheer dhoom & Dashmool kwaha boiled with milk & Q.S. & $\begin{array}{l}8^{\text {th }} \text { to } 14^{\text {th }} \text { day } \\
\text { ( } 7 \text { days) }\end{array}$ \\
\hline Nasya & Karpasasthyadi Taila ${ }^{\mathbf{1 5}}$ & $\begin{array}{l}8 \text { drops in each nos- } \\
\text { trils }\end{array}$ & $\begin{array}{l}1^{\text {th }} \text { to } 14^{\text {th }} \text { day } \\
\text { (14 days) }\end{array}$ \\
\hline Shirobasti & Karpasasthyadi Taila & Q.S. & $\begin{array}{l}15^{\text {th }} \text { to } 21^{\text {th }} \text { day }(7 \\
\text { days) }\end{array}$ \\
\hline Gandusha (Gargaling) & $\begin{array}{l}\text { Ksheer Bala Taila with Dashmool } \\
\text { kwaha }\end{array}$ & $\begin{array}{l}20 \mathrm{ml} \\
100 \mathrm{ml}\end{array}$ & $\begin{array}{l}15^{\text {th }} \text { to } 21^{\text {th }} \text { day } \\
(7 \text { days })\end{array}$ \\
\hline
\end{tabular}

\section{Oral Medication:}

Oral medication was administered as mentioned in table 4 .

Table 4: Oral medication

\begin{tabular}{|l|l|l|l|l|l|}
\hline Sr no & Drugs & Dose & Time of administration & Anupana & Duration \\
\hline 1 & Dhanadhanayanadi Kashaya ${ }^{\mathbf{1 6}}$ & $15 \mathrm{ml}$ & Before meal in morning and evening orally & Lukewarm water & $1 \mathrm{month}$ \\
\hline 2 & Ksheerbala 101 capsule $^{\mathbf{1 7}}$ & 2 capsule & Before meal in morning and evening orally & Lukewarm water & 1 month \\
\hline 3 & Balarishta & $10 \mathrm{ml}$ & After meal in morning and evening orally & Lukewarm water & $1 \mathrm{month}$ \\
\hline 4 & Ashwagandha choorna & $3 \mathrm{gm}$ & After meal in morning and evening orally & Lukewarm milk & $1 \mathrm{month}$ \\
\hline
\end{tabular}

\section{Observation and Results}

After completion of one month of Ayurveda treatment including some of the Panchakarma therapies, the patient got complete symptomatic relief in pain in eyes, watering of eyes with complete closing of eyes as shown in table 5. Marked improvement was seen in deviation of mouth, slurred speech and eating or drinking difficulty as shown in table 5. After completion of Panchakarma therapies along with oral medication, the patient got complete relief in sign and symptoms of the disease. There was marked improvement as assessed by House-Brackmann Facial Nerve Grading scale which was reduced from 4 to 1 as shown in table 5 . 
Table 5: findings of neurological examinations before and after treatment

\begin{tabular}{|c|c|c|}
\hline Neurological Examination & BT & $\mathbf{A T}$ \\
\hline Mini mental function & Conscious well oriented to time place person & Conscious well oriented to time place person \\
\hline Optic nerve & $\begin{array}{l}\text { Field of vision - normal in left and right visual acuity } \\
\text { was } 6 / 6\end{array}$ & $\begin{array}{l}\text { Field of vision - normal in left and right vis- } \\
\text { ual acuity was } 6 / 6\end{array}$ \\
\hline Trochlear nerve & $\begin{array}{l}\text { Pupillary reflex direct - right diminished, left - normal, } \\
\text { indirect - right and left - normal }\end{array}$ & Normal \\
\hline Trigeminal nerve & $\begin{array}{l}\text { Motor Clenching of the jaw - deviated to the left side } \\
\text { Sensory - sensation over the right side - cold, hot - de- } \\
\text { crease, Superficial touch - decrease }\end{array}$ & Normal \\
\hline Facial nerve & $\begin{array}{l}\text { Nasolabial fold absents in the right side } \\
\text { Wrinkles on the forehead - decrease in the right side } \\
\text { Lagophthalmos - right side Tongue deviated toward left } \\
\text { Jaw jerk - negative } \\
\text { Force full closure of the eye - right eye not closed } \\
\text { properly } \\
\text { Blow of cheeks - weakness in the right side } \\
\text { Whistling - not proper } \\
\text { The taste was mildly affected }\end{array}$ & Normal \\
\hline Auditory nerve & Normal & Normal \\
\hline $\begin{array}{l}\text { House-Brackmann } \quad \text { Facial } \\
\text { Nerve Grading }\end{array}$ & 4 & 1 \\
\hline
\end{tabular}

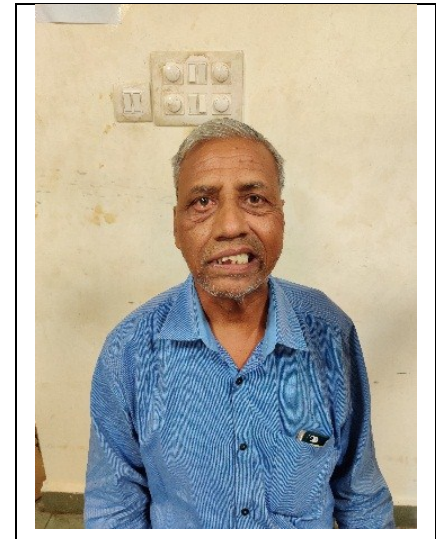

Daviation of mouth towards left side before treatment

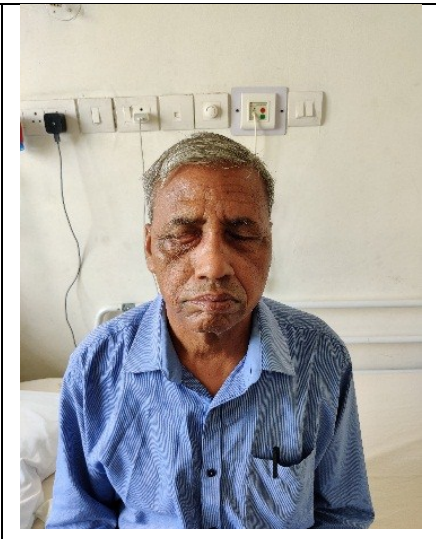

half opened eye before treatment

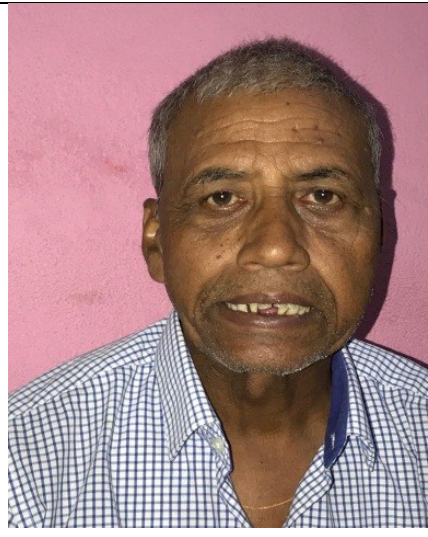

No daviation of mouth after treatment

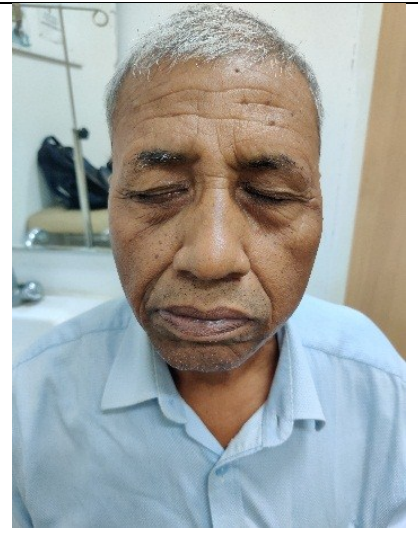

complete eye closer after treatment

\section{DISCUSSION}

In Bell's palsy, facial nerve dysfunction leads to facial muscle paralysis with impairment of both sensory and motor functions. In Ardita, there is mainly vitiation of Vata Dosha. Vata is responsible for all activities of body. So sensory and motor activities can be attained by normalcy of Vata. Here we adopted Brimhana (replenishing/nourishing) type of treatment for correcting the vitiated Vata as per Ayurveda principles of treatment. It improved the motor function by stimulating and strengthening the facial nerves and muscles.

Navana nasya, Moordhni taila, Tarpana chikitsa, Nadiswedana, Upanaha with Anoopa mamsa is the line of treatment mentioned for Ardita. On the basis of line of management of Ardita according to Ayurveda; Nasya with Karpasasthyadi taila, Kukkutanda swedana, Dashmoola ksheer dhoom and Mukha Abhyanga with Ksheerbala Taila have been adopted to overcome the 
aggravated Vata Dosha and to nourish the muscles, improve the blood circulation and stimulate the sensory nerve endings of face and provide strength to the facial muscles. Kukkutanda swedana before the Nasya, enhance local blood circulation by dilation of blood vessels and increasing blood flow to the peripheral arterioles which accelerates the drug absorption and better bioavailability. It also stimulates the local nerves. Kukkutanda and Kshirbala taila are having Snigdha, Guru guna, Ushna veerya, and Vata shamaka properties hence it controls the vitiated Vata. Balya, Brimhaniya properties of both the drugs can nourish and increase the tone of facial muscles. Bala (sida cordifolia) mainly contains ephedrine, an alkaloid which is a CNS stimulant. It increases the activities of neurotransmitter and improve the functioning. ${ }^{18}$ Swedana with Dashmool ksheerdhoom (A decoction prepared by Dashmool kwath with Cow's milk) alleviate Vata and expanding blood flow to the peripheral arterioles which help for quick assimilation of medication. In Nasya therapy, medicated oil is administered through nasal root reaches up to Sringataka Marma (Vital point of junction of blood vessels and nerve endings in the head region) from where it spreads into various Srotas (Channels/blood vessels and nerves) and alleviates the vitiated Doshas. It Provides nourishment to the nervous system by diffusion, neural and vascular pathway hence improve the motor functions of facial nerve. ${ }^{19}$ Shirobasti with Karpasasthyadi Taila has been reported to be having an excellent result on such disorders as it gives strength to the central nervous system particularly brain tissue. It calms down both the mind and the senses which allow the body's natural healing mechanism to release stress from the nervous system by pacifying Vata dosha. The Luke warm oil used in Shirobasti leads to peripheral vasodilation and increases the peripheral circulation which nourishes the tissues, and brings about regenerative changes. ${ }^{20} \mathrm{Gan}$ doosha increase the pressure in the mouth, which stimulates the stretch reflex i.e. the press receptors resulting in stimulation of the salivary nuclei in brain stem. This results increased activity of parasympathetic motor fibres of facial and glossopharyngeal nerves and increases the salivary output, which is further stimulated by the chemical constituents stimulating the oral chemoreceptors and hence the Gandoosha maintains and cures the oral environment. ${ }^{21}$ Dhanadhanayanadi kashaya is administered to pacify vitiated Vatadosha associated with Kapha Pitta. Ashwagandha (Withania somnifera) is observed to have beneficial effects on nervous system as neurotic regeneration and synaptic reconstruction and many more, used as internal medication. ${ }^{22}$ Ksheerabala 101 is concentrated extracts of Bala with milk which is highly nourishing to nervine tissue and advances nerve recovery. It provides strength to muscles due to Balya and Brimhana properties of Bala and Ksheera. It restores the natural functionality of affected nerves and may improves blood circulation to concerned areas of the brain.

\section{CONCLUSION}

Nasya with Karpasasthyadi Taila, Shirobasti with Ksheer Bala Taila, Kukkutanda swedana and Dashmoola ksheer dhoom and Gandoosh with Ksheerabala Taila along with oral medicines like Dhanadhanayanadi Kashaya, Ksheer Bala 101 and Ashwagandha are highly effective in the treatment of Bell's palsy (Ardita Vata) with almost complete recovery.

\section{REFERENCES}

1. Dhruvashree Somasundara, Frank Sullivan, Management of Bell's palsy, Aust Prescr 2017; 40:94-7. DOI: 10.18773/austprescr.2017.030.

2. Fauci, Kasper, Hauser, Longo, Jameson, Loscalzo, editors. Harrison's Principal of Internal Medicine. 19th ed. McGraw Hill Companies; 2015. p. 2436.

3. Gilden DH. Clinical practice. Bell's palsy. N Engl J Med 2004; 351(13):1323-31.

4. Ishii L, Godoy A, Encarnacion CO, Byrne PJ, Boahene $\mathrm{KD}$, Ishii M. Not just another face in the crowd: Society's perceptions of facial paralysis. Laryngoscope 2012; 122:533-8.

5. Acharya YT, Editor, Charaka samhita of Agnivesha, Chikitsa sthana; Vatavyadhi chikitsa, chapter 28, verse 42. Varanasi, Chaukhamba Surbharti Prakashana;2016. P. 618.

6. Peitersen E. The natural history of Bell's palsy. Am J Otol 1982; 4(2):107-11. 
7. Fauci, Kasper, Hauser, Longo, Jameson, Loscalzo, editors. Harrison's Principal of Internal Medicine. 19th ed. McGraw Hill Companies; 2015. p. 2436.

8. Acharya YT, Editor, Charaka samhita of Agnivesha, Chikitsa sthana; Vatavyadhi chikitsa, chapter 28, verse 99. Varanasi, Chaukhamba Surbharti Prakashana;2016. P. 621.

9. House JW, Brackmann DE. Facial nerve grading system. Otolaryngol Head Neck Surg. 1985 Apr;93(2):1467.

10. Khurana Pooja, Pareek Tribhuvan, Saroch Vikas, Pareek R.K, Role of Kukkutanda Swedna and Nasya in the Management of Ardita- A Pilot Study, International journal of ayurvedic \& herbal medicine 4(5) Sep-Oct 2014(1602-1607).

11. Gaurav Sawarkar and Punam Sawarkar., 2019, Management of Ardita (Bell's Palsy) Through Ayurveda- A Case Study. Int J Recent Sci Res. 10(04), pp. 3204032043.

12. Kashinatha Shastri and Gorakhanatha Chaturvedi. Charaka Samhita of Agnivesha with Vidyotini Hindi Commentary Vol. 2, Sidhi Sthana 2/22. Varanasi. Chaukhamba Bharti Academy. 2009. p.986.

13. Nishteswar K, Vidyanath R, editors. Taila Prakarana. In: Sahasrayogam. Varanasi, India: Chaukhambha Sanskrita Series Office; 2017. p. 110.

14. Acharya YT, Editor, Charaka Samhita of Agnivesha, Sutrasthana; Aragvadhiya Adhyaya, chapter 3, verse 18. Varanasi, Chaukhamba Surbharti Prakashana;2016. P. 28-29.

15. Nishteswar K, Vidyanath R, editors. Taila Prakarana. In: Sahasrayogam. Varanasi, India: Chaukhambha Sanskrita Series Office; 2017. p. 118.

16. Anonymous. Sahasrayogam, Director General, New Delhi: CCRAS; 1990.

17. Paradkar HS, editor. Ashtanga hridayam of vagbhata, vatarakta chikitsa; chapter 22, verse 45-46. Varanasi: Chaukhamba Krishnadas Academy; 2006. p. 728.

18. Prajapati ND, Purohit SS, Sharma AK, Kumar T Editors; A Handbook of medicinal plants. Agrobios India: Jodhpur; 2013 p. 475.

19. Tripathi Ravi Dutta, Astangsangrah, reprint 2005, Varanasi, Chaukhambha Sanskrita Pratisthana, sutra sthana chap 31/3, pg.no.528.

20. Anil Gupta. Role of Navana nasya with Mahamasha taila and Shirobasti with ksheerabala taila in the management of Ardita: A comparative clinical study. Int. J. Res. Ayurveda Pharm. 2017;8(6):74-78.
21. Priyavrat Sharma, Susruta Samhita, volume 2, Chikitsa sthana, Chapter 40, verse no 64, Chaukhambha Visvabharati, Varanasi.

22. Singh N, Bhalla M, de Jager P, Gilca M. An overview on ashwagandha: a Rasayana (rejuvenator) of Ayurveda. Afr J Tradit Complement Altern Med. 2011;8(5 Suppl):208-213.

\section{Source of Support: Nil \\ Conflict of Interest: None Declared}

How to cite this URL: Ram Lakhan Meena et al: Complete Management Of Ardita (Bell's Palsy) As Per Ayurveda Chikitsa Sutra - A Case Report. International Ayurvedic Medical Journal \{online\} 2021 \{cited March, 2021\} Available from:

http://www.iamj.in/posts/images/upload/650_656.pdf 